\title{
ORGANISATION AND FINANCING OF FOOTBALL CLUBS IN CROATIA
}

\author{
Anto Bajo \\ University of Zagreb, Faculty of Economics and Business, Zagreb, Croatia \\ Institute of Public Finance, Zagreb
}

\section{Marko Primorac}

University of Zagreb, Faculty of Economics and Business, Zagreb, Croatia

\section{Lucija Grubisic}

University of Zagreb, Faculty of Economics and Business, Zagreb, Croatia

\section{OMESTE}

JEL Category: G240, G310, D920

\begin{abstract}
The football has been gradually transformed from a sport game and a popular social phenomenon into a market activity attracting significant foreign investment all over the world. Clubs are increasingly investing in the transfer of players which is why this sector grips attention in the economy and fiscal systems. There is a set of dilemmas relating to the legal status of football clubs in Croatia, their accounting policies and tax liabilities, but also the subsidies they receive from the public sector. It is reasonable to wonder to what extent football remained in the area of public - sport and financial - interest and to what extent is it subject to private interests, driven by profit motives. To the extent they are dominated by private interests, football clubs should be deprived of preferential tax treatment, significant public subsidies and other benefits enjoyed at the burden of the public sector.
\end{abstract}

Keywords: football, financing, organisation, performance, indicator

\section{INTRODUCTION}

The main objective of this paper is to perform the financial analysis of business activities of football clubs in Croatia. The analysis includes clubs from first and second Croatian football league (cro.

Address of the corresponding author: Anto Bajo 莑=”' bajo@ijf.hr
Hrvatska nogometna liga - HNL), according to the current schedule for the season 2015/2016. HNL I includes 10 and HNL II additional 12 clubs.

We analyse the structure of revenues and expenditures, as well as assets, liabilities and capital of football clubs. Finally, through the calculation of selected financial ratios we assess their relative success in business operations, but also point to the problems associated with their liquidity and indebtedness. It should be noted that 
one of the second league clubs (Dinamo II) is actually the reserve team of the first league club Dinamo. For this reason the financial analysis includes 21 rather than 22 football clubs.

Finally, based on the calculation of selected financial indicators we assess their relative business success and point out to the potential problems relating to their liquidity and indebtedness. Based on their financial results and the incurrence of liabilities we judge whether football in Croatia grew from financially less important social activity (with obvious public benefits) to a serious economic branch with prevalent private interests. The financial analysis should reveal the stage of transition of Croatian football clubs to professional sports. Results of the financial analysis should indicate whether Croatia needs a better regulation of the financial operations of the football sector and the establishment of a stable legal and institutional infrastructure for the long-term sustainability.

\section{LEGAL STATUS, ACCOUNTING OF FOOTBALL CLUBS AND PLAYERS}

Today, sporting success is not the only a way to measure the football club's performance (Van Uden, 2005), nor are fans the only interest group with expectations related to the club's performance (Mason, 1999). Therefore, these organisations have to design new strategies and objectives in order to adapt to a sector that has been challenged by professionalization and commercialisation; processes that have affected sport in general, but especially the most popular sport branches and those with the greatest media coverage. These processes and their consequences have lead sports to be considered as a business (Chadwick and Beech, 2004), an industry (Foster, Greyser et al, 2005), or an economic sector, capable of generating value for all actors partaking in it (Gomez, Marti, Opazo, 2008).

In North America it is commonplace, especially among economists, to think of the owners of professional sports teams as profit maximisers. In Europe, however, this assumption has been treated somewhat sceptically. Sloane (1971) argued that a plausible characterisation of the owners of football clubs is as "utility maximisers" subject to a budget constraint, where utility is largely associated with success on the pitch. Reasons for this view include the perceived lack of profitability of football clubs and the opinions expressed by club officials. In some countries football clubs are organised as sporting associations which have no shareholders, but in England all professional clubs are limited companies, and most have been so for around 100 years.

Financial reporting of clubs in Croatia is not uniform because some clubs use non-profit accounting, and others for-profit accounting. For this reason were certain items from financial statements of clubs set up as non-profit organizations modified to reflect the structure of financial statements of public limited companies. Although this process can not be completely accurate in all parts of the report, it is necessary for making the comparative analysis possible.

In countries where football is popular, the economic weight of professional football increases from season to season and today plays an incredible economic role. Besides increasing the total revenues of professional football clubs, an extraordinary rise in investments can also be observed. Another unique feature is, therefore, that the football industry can only accumulate reserves to a limited extent. The value of assets invested into the sector is constantly on the rise and the improvement of financial/investment opportunities is also a worldwide tendency. The growth in value of player portfolio and squads has now reached an extraordinary (according to certain opinions exaggerated) extent. This fact is supported by the remarkably high transfer fees. In recent years, the increase in equity capital could also be observed, which is very positive since the equity capital is the engine of any enterprise. Unfortunately, this increase is prominent only in the case of certain larger football clubs, while in general the level of indebtedness in professional football is on the rise in many countries. This is the reason why the reduction of debt is still considered a priority in the industry both in the long and short term (Nagy, 2012).

Mourão (2005) provides a deeper analysis of the finances of football; the costs of football teams depend on the divisions in which the teams play and include the costs of salaries, maintenance of infrastructure, and movements of personnel and investments. Football teams' funding may come 
from receipts, transfers made by the state, sponsorships, members' contributions, sell sheets, merchandising practices, and bank debt (Mourão, 2005).

Football clubs' balance sheets can be quite interesting since players are usually registered on the balance sheet as assets. The records of right to registration of players in the financial statements is supported by the International Accounting Standard (IAS) 38, which prescribes the recognition and registration of intangible assets that are not specifically dealt with in other international accounting standards. According to IAS 38, an intangible asset is non-monetary asset without physical substance, which can be identifiable. In accounting terms, an asset is a resource - controlled by an entity in whose reports it is registered - which is expected to generate future economic benefits. An asset is identifiable when it is separable, and derives from a contract or other legal rights. Finally, IAS 38 prescribes that intangible assets should be recognized only if the cost of acquiring an asset can be determined reliably.

Morrow (1997) argues justification of accounting records of right to registration of players as intangible assets on the basis of these criteria. Players who have entered into an agreement with certain clubs are associated with those clubs for a certain period of time in which they are expected to generate economic benefits for the clubs. In addition, the fact that the right emerges from the contract, as well as the right to sell players (separation of rights to players from other assets of the club), confirm the identifiability of the asset. Since players are usually bought for a fee (unlike other employees), the cost of acquiring players can be determined reliably and therefore recorded in the financial statements, in line with the IAS 38. Of course, given the duration of the contract, this intangible asset is also depreciating in the financial statements and amortizing within the stipulated period, mostly without residual value.

In order to prevent swapping between clubs during the season, the English Football Association already in 1885 prescribed the registration of all players (Morrow, 1997). The transfer market for players was developed as a result of these provisions. With the registration of players the club reserves the right to hold players for the duration of the contract. If another club wants to 'buy' a player for the duration of the contract, it has to pay a fee for the transfer of that right to the home club. It should be noted that - although it is not quite logical - the players who were not purchased but have grown up in the club can not be recorded on the balance sheet because they do not meet all the criteria laid down in the IAS 38. In fact, considering that these players are not purchased for a fee, the acquisition cost for them can not be determined (UEFA 2012).

\section{CROATIAN FOOTBALL LEAGUE ORGANISATIONS \& FINANCING}

In Croatia there are currently seven football leagues. These are the first (I), second (II) and third (III) Croatian football league (cro. Hrvatska nogometna liga - HNL), and first, second, third and fourth county football league (cro. Županijska nogometna liga - ŽNL). The analysis encompasses clubs from the first and second HNL (according to the current schedule for season 2015/2016). HNL I includes 10, and HNL || 12 clubs.

Football clubs in Croatia operate as non-profit organizations or as public limited companies. In HNL I, both legal forms are equally represented. Clubs from HNL II are generally established as non-profit organizations.

Clubs that strive for the development of sports infrastructure, young athletes and the local community, creating positive external effects (externalities) through promotion of sports values in the society should be organized as non-profit organizations. It is logical that such - mostly amateur - clubs are largely financed by public funds. However, professional clubs focused on generating income (which is not necessarily used for the development of their own players but acquisition of better - professional athletes), should not enjoy the status of non-profit organizations.

\section{STRUCTURE OF HNL}

The average number of players in the first league clubs is 32 , the average age of players being 23.5 years, while in the second league teams on average consist of 25 players, with average age of 24 years (Table 1 ). 
Bajo A. Organisation and financing of football clubs in Croatia

MEST Journal Vol. 4 No. 2 pp. 11-22

Table 1 Structure of HNL I and HNL // teams in 2015

\begin{tabular}{|c|c|c|c|c|c|c|}
\hline No & Football club & $\begin{array}{c}\text { Total } \\
\text { players }\end{array}$ & $\begin{array}{l}\text { Average } \\
\text { age }\end{array}$ & $\begin{array}{l}\text { Foreign } \\
\text { players }\end{array}$ & $\begin{array}{c}\text { Total market } \\
\text { value of players } \\
\text { (mil. HRK) }\end{array}$ & $\begin{array}{c}\text { Average market } \\
\text { value of players } \\
\text { (mil. HRK) }\end{array}$ \\
\hline & HNL I & & & & & \\
\hline 1 & Dinamo & 41 & 23.8 & 18 & 415.12 & 10.16 \\
\hline 2 & Rijeka & 40 & 25.1 & 14 & 265.22 & 6.63 \\
\hline 3 & Hajduk & 35 & 22.9 & 9 & 181.21 & 5.18 \\
\hline 4 & Split & 32 & 24.9 & 4 & 94.78 & 2.96 \\
\hline 5 & Lokomotiva & 32 & 22.8 & 3 & 70.89 & 2.21 \\
\hline 6 & Slaven Belupo & 31 & 24.7 & 5 & 58.76 & 1.90 \\
\hline 7 & Istra 1961 & 30 & 24.6 & 11 & 54.97 & 1.83 \\
\hline 8 & Zagreb & 24 & 22.8 & 4 & 54.21 & 2.26 \\
\hline 9 & Osijek & 31 & 24.4 & 5 & 45.49 & 1.47 \\
\hline \multirow[t]{3}{*}{10} & Inter Zaprešić & 27 & 23.3 & 7 & 26.01 & 0.96 \\
\hline & TOTAL HNL I: & 319 & 23.5 & 78 & $1,257.49$ & 3.94 \\
\hline & HNL II & & & & & \\
\hline 1 & Zadar & 26 & 27.1 & 4 & 38.67 & 1.49 \\
\hline 2 & Hrvatski dragovoljac & 27 & 24.4 & 5 & 22.22 & 0.82 \\
\hline 3 & Gorica & 27 & 25.7 & 1 & 20.70 & 0.77 \\
\hline 4 & Šibenik & 27 & 24.9 & 1 & 12.89 & 0.48 \\
\hline 5 & Dugopolje & 32 & 23.9 & 3 & 10.08 & 0.31 \\
\hline 6 & Rudeš & 29 & 24.3 & 2 & 9.86 & 0.34 \\
\hline 7 & Lučko & 30 & 22.3 & 3 & 9.86 & 0.33 \\
\hline 8 & Sesvete & 21 & 25.0 & 2 & 9.33 & 0.44 \\
\hline 9 & Cibalia & 19 & 23.3 & 4 & 7.96 & 0.42 \\
\hline 10 & Imotski & 23 & 26.3 & 1 & 6.26 & 0.27 \\
\hline 11 & Segesta & 28 & 24.9 & 1 & 4.93 & 0.17 \\
\hline \multirow[t]{3}{*}{12} & Dinamo II & 11 & 19.7 & 1 & 1.52 & 0.14 \\
\hline & TOTAL HNL II: & 300 & 24.0 & 28 & 154.14 & 0.51 \\
\hline & TOTAL HNL I \& II: & 619 & 23.8 & 106 & $1,411.64$ & 2.28 \\
\hline
\end{tabular}

Note: The value of players is converted to HRK according to the according to the CNB middle exchange rate as of July 1, 2015 of 7.582113 HRK for 1 euro

Source: www.transfermarkt.co.uk

Table 2 Clubs with highest amount of profit generated through the transfer of players from season 1995/96 to 2015/16 (in million HRK)

\begin{tabular}{|c|l|r|r|r|r|r|}
\hline No & Football clubs & $\begin{array}{c}\text { Number of buy } \\
\text { transactions }\end{array}$ & Expenditure & $\begin{array}{c}\text { Number of sell } \\
\text { transactions }\end{array}$ & Revenue & Profit \\
\hline 1 & Dinamo & 449 & 407.84 & 457 & $1,423.69$ & $1,015.93$ \\
\hline 2 & Hajduk & 467 & 98.87 & 508 & 571.01 & 472.14 \\
\hline 3 & Rijeka & 325 & 40.49 & 318 & 157.63 & 117.14 \\
\hline 4 & Zagreb & 219 & 3.68 & 236 & 117.75 & 114.11 \\
\hline 5 & Osijek & 236 & 0.53 & 262 & 104.03 & 103.50 \\
\hline 6 & Split & 158 & 6.26 & 143 & 81.13 & 74.91 \\
\hline 7 & Lokomotiva & 229 & 6.44 & 207 & 60.13 & 53.68 \\
\hline 8 & Inter Zaprešić & 297 & 1.02 & 295 & 58.46 & 57.47 \\
\hline 9 & Slaven Belupo & 211 & 0.49 & 212 & 56.11 & 55.58 \\
\hline 10 & Varaždin & 194 & 0.03 & 254 & 46.40 & 46.40 \\
\hline
\end{tabular}

Note: The value of players is converted to HRK according to the according to the CNB middle exchange rate as of July 1, 2015 of 7.582113 HRK for 1 euro

Source: www.transfermarkt.co.uk

The average value of players in HNL I is about HRK $4 \mathrm{~m}$, whereby players of Dinamo Zagreb are the most expensive, whereas those of Inter Zaprešić are the cheapest. The average value of the second league players is about HRK $0.5 \mathrm{~m}$. The total market value of HNL II clubs is, therefore, only slightly higher than HRK $154 \mathrm{~m}$ and those of HNL I nearly HRK $1.3 \mathrm{bn}$. From a total of 319 players in $\mathrm{HNL} \mathrm{I}$, there are 78 foreign players, and in HNL II only 28 of a total of 300 players are foreign. This is logical since the clubs from the first league realize the most buys and sells of players (table 2).

From season $1995 / 96$ to $2015 / 16$, ten clubs with the highest profit from the transfer of players have 
completed from a total of 448 (Varaždin) to 906 (Dinamo), transactions (table 2). Earnings from the transfer of players for Dinamo in the past twenty years reached over HRK 1 bn.

The top ten clubs list with the highest profit from transfers is mainly composed of teams from the first league, with the exception of Istra 1961, which is surpassed by Varaždin - the club from the third league. It is therefore likely that these clubs are financially much more successful than the second league clubs. Financial analysis will reveal differences in operations between clubs from the first and the second league.

\section{REVENUE AND EXPENDITURE OF CROATIAN FOOTBALL LEAGUE}

Total revenues of the Croatian first league clubs in 2014 were ten times higher than those of second league clubs (Table 3). Dinamo generated the highest amount of revenue, while second-placed Hajduk achieved almost half of that amount. Expenditures of observed clubs were generally significantly higher than revenues. Accordingly, HNL I clubs achieved a cumulative loss of nearly HRK 122m, and HNL II clubs about HRK 4m. In HNL I, only Zagreb, Lokomotiva and Istra 1961 achieved the positive financial result.

Table 3 Operating results of football clubs in 2014 (in thousands of HRK)

\begin{tabular}{|c|c|c|c|c|c|}
\hline No & Football club & Type & Revenue & Expenditure & Profit/loss \\
\hline & HNL I & & & & \\
\hline 1 & Dinamo & npo & 120,925 & 211,373 & $-90,448$ \\
\hline 2 & Zagreb (2013) & npo & 16,830 & 14,438 & 2,391 \\
\hline 3 & Lokomotiva & npo & 33,680 & 33,044 & 636 \\
\hline 4 & Slaven Belupo & npo & 14,881 & 16,208 & $-1,326$ \\
\hline 5 & Hajduk & plc & 69,385 & 75,329 & $-5,944$ \\
\hline 6 & Rijeka & plc & 67,431 & 81,799 & $-14,368$ \\
\hline 7 & Split & plc & 30,839 & 36,920 & $-6,081$ \\
\hline 8 & Osijek & plc & 9,439 & 14,002 & $-4,563$ \\
\hline 9 & Istra 1961 & plc & 17,390 & 17,353 & 37 \\
\hline \multirow[t]{3}{*}{10} & Inter Zaprešić & npo & 6,513 & 8,351 & $-1,838$ \\
\hline & TOTAL HNL I: & & 387,313 & 508,817 & $-121,504$ \\
\hline & HNL II: & & & & \\
\hline 1 & Cibalia & plc & 5,568 & 10,285 & $-4,717$ \\
\hline 2 & Zadar & plc & 7,492 & 9,180 & $-1,688$ \\
\hline 3 & Dugopolje & npo & 2,876 & 2,795 & 82 \\
\hline 4 & Gorica & npo & 3,614 & 3,609 & 6 \\
\hline 5 & Hrvatski dragovoljac & npo & 6,402 & 4,501 & 1,902 \\
\hline 6 & Imotski & npo & 1,147 & 1,332 & -185 \\
\hline 7 & Lučko & npo & 1,554 & 1,698 & -144 \\
\hline 8 & Rudeš & npo & 2,376 & 2,083 & 293 \\
\hline 9 & Segesta & npo & 1,142 & 1,440 & -298 \\
\hline 10 & Sesvete & npo & 1,945 & 1,320 & 625 \\
\hline \multirow[t]{3}{*}{11} & Šibenik & plc & 2,995 & 2,721 & 274 \\
\hline & TOTAL HNL II: & & 37,111 & 40,962 & $-3,851$ \\
\hline & TOTAL HNL I \& II: & & 424,424 & 549,780 & $-125,355$ \\
\hline
\end{tabular}

Note: npo - non-profit organization; plc - public limited company.

Source: Football clubs' financial statements for 2014

The largest loss (over HRK 90m) was made by Dinamo, which generates almost one third of total revenues of all football clubs from $\mathrm{HNL} I$ and $\mathrm{HNL}$ II. Given the dominance of Dinamo compared to other clubs observed, the analysis is carried out with special reference to Dinamo's business operations.
Operating revenues are predominantly represented in all clubs (Table 4). Dinamo Zagreb, Lokomotiva and Slaven Belupo have relatively high other revenues - mainly from the sale of fixed assets and other miscellaneous revenues. Financial statements are not entirely clear on items included in other revenues, which are high making the financial reporting in football clubs less transparent. 
Bajo A. Organisation and financing of football clubs in Croatia

MEST Journal Vol. 4 No. 2 pp. 11-22

Table 4 Structure of revenues of football clubs in 2014 (in HRK thousands)

\begin{tabular}{|c|c|c|c|c|c|c|}
\hline No & Football club & Type & Total & Operating & Financial & Other \\
\hline & HNL I & & & & & \\
\hline 1 & Dinamo & npo & 120,925 & 57,808 & 597 & 62,519 \\
\hline 2 & Zagreb (2013) & npo & 16,830 & 7,655 & 73 & 9,102 \\
\hline 3 & Lokomotiva & npo & 33,680 & 5,208 & 52 & 28,420 \\
\hline 4 & Slaven Belupo & npo & 14,881 & 7,953 & 138 & 6,791 \\
\hline 5 & Hajduk & plc & 69,385 & 62,475 & 1,696 & 5,214 \\
\hline 6 & Rijeka & plc & 67,431 & 67,251 & 180 & 0 \\
\hline 7 & Split & plc & 30,839 & 30,511 & 328 & 0 \\
\hline 8 & Osijek & plc & 9,439 & 9,439 & 0 & 0 \\
\hline 9 & Istra 1961 & plc & 17,390 & 17,390 & 0 & 0 \\
\hline \multirow[t]{3}{*}{10} & Inter Zaprešić & npo & 6,513 & 6,513 & 0 & 0 \\
\hline & TOTAL HNL I & & 387,313 & 272,204 & 3,063 & 112,046 \\
\hline & HNL II & & & & & \\
\hline 1 & Cibalia & plc & 5,568 & 5,565 & 4 & 0 \\
\hline 2 & Zadar & plc & 7,492 & 7,491 & 1 & 0 \\
\hline 3 & Dugopolje & npo & 2,876 & 2,829 & 0 & 47 \\
\hline 4 & Gorica & npo & 3,614 & 3,527 & 0 & 87 \\
\hline 5 & Hrvatski dragovoljac & npo & 6,402 & 4,979 & 0 & 1,424 \\
\hline 6 & Imotski & npo & 1,147 & 1,092 & 0 & 55 \\
\hline 7 & Lučko & npo & 1,554 & 1,554 & 0 & 0 \\
\hline 8 & Rudeš & npo & 2,376 & 2,376 & 0 & 0 \\
\hline 9 & Segesta & npo & 1,142 & 1,084 & 0 & 58 \\
\hline 10 & Sesvete & npo & 1,945 & 1,945 & 0 & 0 \\
\hline \multirow[t]{3}{*}{11} & Šibenik & plc & 2,995 & 2,995 & 0 & 0 \\
\hline & TOTAL HNL II: & & 37,111 & 35,436 & 4 & 1,671 \\
\hline & TOTAL HNL I \& II: & & 424,424 & 307,640 & 3,067 & 113,717 \\
\hline
\end{tabular}

Note: npo - non-profit organization; plc - public limited company.

Source: Football clubs' financial statements for 2014

Table 5 Structure of expenditure of football clubs in 2014 (in HRK thousands)

\begin{tabular}{|c|c|c|c|c|c|c|}
\hline No & Football club & Type & $\begin{array}{c}\text { Total } \\
(1+2+3)\end{array}$ & $\begin{array}{c}\text { Operating } \\
\text { (1) }\end{array}$ & $\begin{array}{l}\text { Financial } \\
\text { (2) }\end{array}$ & $\begin{array}{l}\text { Other } \\
\text { (3) }\end{array}$ \\
\hline & HNL I & & & & & \\
\hline 1 & Dinamo & npo & 211,373 & 190,097 & 7,738 & 13,538 \\
\hline 2 & Zagreb (2013.) & npo & 14,438 & 12,696 & 1,055 & 688 \\
\hline 3 & Lokomotiva & npo & 33,044 & 30,527 & 174 & 2,343 \\
\hline 4 & Slaven Belupo & npo & 16,208 & 16,050 & 155 & 3 \\
\hline 5 & Hajduk & plc & 75,329 & 70,127 & 3,200 & 2,002 \\
\hline 6 & Rijeka & plc & 81,799 & 81,463 & 336 & 0 \\
\hline 7 & Split & plc & 36,920 & 35,614 & 1,306 & 0 \\
\hline 8 & Osijek & plc & 14,002 & 13,949 & 53 & 0 \\
\hline 9 & Istra 1961 & plc & 17,353 & 16,673 & 680 & 0 \\
\hline \multirow[t]{3}{*}{10} & Inter Zaprešić & npo & 8,351 & 8,273 & 78 & 0 \\
\hline & TOTAL HNL I: & & 508,817 & 475,468 & 14,775 & 18,574 \\
\hline & HNL II & & & & & \\
\hline 1 & Cibalia & plc & 10,285 & 8,781 & 1,504 & 0 \\
\hline 2 & Zadar & plc & 9,180 & 3,292 & 2,036 & 3,853 \\
\hline 3 & Dugopolje & npo & 2,795 & 2,689 & 21 & 85 \\
\hline 4 & Gorica & npo & 3,609 & 2,754 & 19 & 835 \\
\hline 5 & Hrvatski dragovoljac & npo & 4,501 & 4,217 & 21 & 262 \\
\hline 6 & Imotski & npo & 1,332 & 1,282 & 32 & 18 \\
\hline 7 & Lučko & npo & 1,698 & 1,620 & 78 & 0 \\
\hline 8 & Rudeš & npo & 2,083 & 1,646 & 52 & 385 \\
\hline 9 & Segesta & npo & 1,440 & 1,422 & 1 & 17 \\
\hline 10 & Sesvete & npo & 1,320 & 1,311 & 8 & 0 \\
\hline \multirow[t]{3}{*}{11} & Šibenik & plc & 2,721 & 2,390 & 332 & 0 \\
\hline & TOTAL HNL II: & & 40,962 & 31,403 & 4,104 & 5,455 \\
\hline & TOTAL I \& II: & & 549,780 & 506,872 & 18,879 & 24,029 \\
\hline
\end{tabular}

Note: npo - non-profit organization; plc-public limited company.

Source: Football clubs' financial statements for 2014 
The football clubs' expenditures structure is dominated by the operating expenditures (for employees, material expenditures, amortization and depreciation and donations). From a total of HRK $550 \mathrm{~m}$ of first and second league football clubs' expenditures in 2014, Dinamo achieved almost half (Table 5).

The success of clubs in achieving financial results can be estimated by comparing their financial indicators - turnover ratios, indicators of effectiveness and profitability ratios (Table 6).

Total assets turnover ratio is the ratio of total revenue to total assets, which shows how many monetary units of revenues is generated by each monetary unit of assets. The higher the ratio the club is considered to be more successful in the use of available assets. The average total assets turnover ratio in $\mathrm{HNL} I$ is 0.53 , and in $\mathrm{HNL}$ II 0.88 . This means that HNL II clubs are much more successful in achieving the financial results than HNL I clubs. This is confirmed by other indicators as well.

Indicator of effectiveness of overall operations is calculated as the ratio of total revenues and total expenditures. It is - therefore - preferable the higher the value of this indicator. Logically, if the value is less than 1 , the club operates at a loss. The average effectiveness of overall operations of HNL I clubs in 2014 was 0.76 , and in HNL II 0.91 . Net profit margin is the ratio of net profit and total income, and is calculated to determine the capability of generating a profit in relation to the accumulated revenues. The HNL II clubs are with an average net profit margin of $-0.1-$ also by this indicator considerably more successful than the HNL I clubs with the average value of this indicator of less than -0.3 . This fact is even more devastating taken into account that $10 \mathrm{HNL}$ I clubs employ a total of 309 , and $11 \mathrm{HNL}$ II only 90 employees (table 6).

\section{BUSINESS PERFORMANCES AND FINANCIAL POSITION}

Total assets of HNL II clubs is only a bit higher than HRK $42 \mathrm{~m}$, while HNL I clubs' assets are even 17 times more valuable - amounting to HRK $731 \mathrm{~m}$ (Table 7). Dinamo and Hajduk together have over HRK $538 \mathrm{~m}$ in assets. Rijeka also stands out with its financial domination. Because of the uneven accounting framework certain adjustments to the items in the financial statements of clubs operating as non-profit organizations had to be made for analysing the structure of assets and liabilities. The assets of non-profit organizations are not classified in reports only as long-term and shortterm, but are also divided into produced and nonproduced long-term assets, small inventory, nonfinancial assets in preparation, produced shortterm assets and financial assets (without division into long-term and short-term). Keeping in mind the deficiencies of such classification and specifics of football clubs' operations in Croatia (which in principle should not have large amounts of long-term financial assets), their financial assets are entirely classified as short-term assets, as well as small inventory, non-financial assets in preparation and produced short-term assets. Other asset items are classified as long-term assets.

Most of assets consist of intangible assets - rights to players - which are recorded in the balance sheet in accordance with the IAS 38 and amortized annually. Long-term (produced and non-produced) assets of Dinamo in 2014 amounted to around HRK $150 \mathrm{~m}$.

The financing structure of football clubs is dominated by liabilities. Total liabilities of HNL I clubs amount to over HRK $600 \mathrm{~m}$, while their own financing sources stood at slightly less than HRK $125 \mathrm{~m}$ (Table 8). HNL II clubs have nearly HRK $36 \mathrm{~m}$ liabilities and just over HRK $6 \mathrm{~m}$ of own capital. While it is not unusual for legal entities to borrow in order to finance profitable assets, such a large disproportion of own financing sources and liabilities of football clubs is - due to the specifics of the sector - indeed worrying. Particularly alarming is the finding that of 21 clubs covered with the analysis, 10 clubs (4 from HNL I and 6 from HNL II) have a negative value of capital. This means that their liabilities exceed total assets, i.e. when total assets would be converted into cash at book value, that amount would not be sufficient to cover the liabilities. A negative value of capital emerges as a consequence of the loss in excess of capital, which makes liabilities become greater than assets.

About $34 \%$ of short-term and over $50 \%$ of longterm liabilities of both HNL I \& II football clubs together refers to the liabilities of Dinamo. Liabilities for loans to banks and other creditors of Dinamo in 2014 increased almost seven times. By far the greatest part of newly created liabilities relates to loans from banks and other creditors abroad. 
Bajo A. Organisation and financing of football clubs in Croatia

MEST Journal Vol. 4 No. 2 pp. 11-22

Table 6 Indicators of turnover, effectiveness and profitability of football clubs in 2014

\begin{tabular}{|c|c|c|c|c|c|c|}
\hline No & Football club & Type & Employees & $\begin{array}{c}\text { Assets } \\
\text { turnover ratio }\end{array}$ & $\begin{array}{l}\text { Effectiveness of } \\
\text { overall operations }\end{array}$ & $\begin{array}{l}\text { Net profit } \\
\text { margin }\end{array}$ \\
\hline & HNL I & & & & & \\
\hline 1 & Dinamo & npo & 86 & 0.38 & 0.57 & -0.75 \\
\hline 2 & Zagreb & npo & 16 & 6.08 & 1.17 & 0.14 \\
\hline 3 & Lokomotiva & npo & 32 & 1.80 & 1.02 & 0.02 \\
\hline 4 & Slaven Belupo & npo & 17 & 3.02 & 0.92 & -0.09 \\
\hline 5 & Hajduk & plc & 66 & 0.32 & 0.92 & -0.09 \\
\hline 6 & Rijeka & plc & 17 & 1.11 & 0.82 & -0.21 \\
\hline 7 & Split & plc & 30 & 0.73 & 0.84 & -0.20 \\
\hline 8 & Osijek & plc & 18 & 0.23 & 0.67 & -0.48 \\
\hline 9 & Istra 1961 & plc & 19 & 0.83 & 1.00 & 0.00 \\
\hline \multirow[t]{3}{*}{10} & Inter Zaprešić & npo & 8 & 5.21 & 0.78 & -0.28 \\
\hline & TOTAL HNL I: & & 309 & 0.53 & 0.76 & -0.31 \\
\hline & HNL II & & & & & \\
\hline 1 & Cibalia & plc & 17 & 0.40 & 0.54 & -0.85 \\
\hline 2 & Zadar & plc & 13 & 0.62 & 0.82 & -0.23 \\
\hline 3 & Dugopolje & npo & 7 & 7.16 & 1.03 & 0.03 \\
\hline 4 & Gorica & npo & 11 & 4.75 & 1.00 & 0.00 \\
\hline 5 & Hrvatski dragovoljac & npo & 9 & 6.98 & 1.42 & 0.30 \\
\hline 6 & Imotski & npo & 1 & 25.07 & 0.86 & -0.16 \\
\hline 7 & Lučko & npo & 7 & 0.23 & 0.91 & -0.09 \\
\hline 8 & Rudeš & npo & 4 & 4.32 & 1.14 & 0.12 \\
\hline 9 & Segesta & npo & 0 & 3.83 & 0.79 & -0.26 \\
\hline 10 & Sesvete & npo & 9 & 0.40 & 1.47 & 0.32 \\
\hline \multirow[t]{3}{*}{11} & Šibenik & plc & 12 & 2.13 & 1.10 & 0.09 \\
\hline & TOTAL HNL II: & & 90 & 0.88 & 0.91 & -0.10 \\
\hline & TOTAL HNL I \& II: & & 399 & 0.55 & 0.77 & -0.30 \\
\hline
\end{tabular}

Note: npo - non-profit organization; plc - public limited company. Source: Football clubs' financial statements for 2014

Table 7 Structure of assets of football clubs in 2014 (in HRK thousands)

\begin{tabular}{|c|c|c|c|c|c|c|}
\hline \multirow{2}{*}{ No } & \multirow{2}{*}{ Football club } & \multirow{2}{*}{ Type } & \multirow{2}{*}{ Total } & \multicolumn{2}{|c|}{ Assets } & \multirow{2}{*}{$\begin{array}{l}\text { Expenditures of } \\
\text { future periods }\end{array}$} \\
\hline & & & & Long-term & Short-term & \\
\hline & HNL I & & & & & \\
\hline 1 & Dinamo & npo & 318,733 & 148,588 & 141,031 & 29,113 \\
\hline 2 & Zagreb & npo & 2,770 & 233 & 2,537 & 0 \\
\hline 3 & Lokomotiva & npo & 18,669 & 8,960 & 9,708 & 0 \\
\hline 4 & Slaven Belupo & npo & 4,924 & 1,614 & 2,249 & 1,060 \\
\hline 5 & Hajduk & plc & 219,444 & 185,136 & 31,945 & 2,363 \\
\hline 6 & Rijeka & plc & 60,600 & 16,691 & 43,451 & 459 \\
\hline 7 & Split & plc & 42,528 & 36,415 & 6,113 & 0 \\
\hline 8 & Osijek & plc & 41,544 & 39,714 & 1,330 & 500 \\
\hline 9 & Istra 1961 & plc & 20,937 & 18,518 & 2,379 & 40 \\
\hline \multirow[t]{3}{*}{10} & Inter Zaprešić & npo & 1,250 & 26 & 1,224 & 0 \\
\hline & TOTAL HNL I: & & 731,399 & 455,897 & 241,968 & 33,534 \\
\hline & HNL II & & & & & \\
\hline 1 & Cibalia & plc & 14,029 & 11,521 & 2,508 & 0 \\
\hline 2 & Zadar & plc & 12,130 & 1,686 & 10,444 & 0 \\
\hline 3 & Dugopolje & npo & 402 & 194 & 208 & 0 \\
\hline 4 & Gorica & npo & 761 & 109 & 651 & 0 \\
\hline 5 & Hrvatski dragovoljac & npo & 917 & 86 & 830 & 0 \\
\hline 6 & Imotski & npo & 46 & 0 & 46 & 0 \\
\hline 7 & Lučko & npo & 6,712 & 6,382 & 330 & 0 \\
\hline 8 & Rudeš & npo & 550 & 169 & 381 & 0 \\
\hline 9 & Segesta & npo & 298 & 58 & 133 & 107 \\
\hline 10 & Sesvete & npo & 4,890 & 4,705 & 185 & 0 \\
\hline \multirow[t]{3}{*}{11} & Šibenik & plc & 1,403 & 18 & 1,385 & 0 \\
\hline & TOTAL HNL II: & & 42,137 & 24,928 & 17,102 & 107 \\
\hline & TOTAL HNL I \& II: & & 773,536 & 480,825 & 259,070 & 33,640 \\
\hline
\end{tabular}

Note: npo - non-profit organization; plc - public limited company.

Source: Football clubs' financial statements for 2014 

MEST Journal Vol. 4 No. 2 pp. 11-22

Table 8 Structure of capital and financing sources of football clubs in 2014 (in HRK thousands)

\begin{tabular}{|c|c|c|c|c|c|c|}
\hline \multirow{2}{*}{ No } & \multirow{2}{*}{ Football club } & \multirow{2}{*}{ Total } & \multirow{2}{*}{$\begin{array}{l}\text { Capital and } \\
\text { reserves }\end{array}$} & \multicolumn{2}{|c|}{ Liabilities } & \multirow{2}{*}{$\begin{array}{l}\text { Revenues of } \\
\text { future periods }\end{array}$} \\
\hline & & & & Short-term & Long-term & \\
\hline & $\mathrm{HNL}$ & & & & & \\
\hline 1 & Dinamo & 318,733 & 46,629 & 103,728 & 167,534 & 842 \\
\hline 2 & Zagreb & 2,770 & $-12,531$ & 4,696 & 10,605 & 0 \\
\hline 3 & Lokomotiva & 18,669 & 5,543 & 10,342 & 2,782 & 1 \\
\hline 4 & Slaven Belupo & 4,924 & 778 & 3,259 & 886 & 0 \\
\hline 5 & Hajduk & 219,444 & 135,063 & 63,405 & 17,053 & 3,922 \\
\hline 6 & Rijeka & 60,600 & 10,508 & 49,693 & 239 & 161 \\
\hline 7 & Split & 42,528 & $-30,659$ & 10,087 & 63,101 & 0 \\
\hline 8 & Osijek & 41,544 & $-33,584$ & 11,613 & 63,516 & 0 \\
\hline 9 & Istra 1961 & 20,937 & 4,061 & 16,877 & 0 & 0 \\
\hline \multirow[t]{3}{*}{10} & Inter Zaprešić & 1,250 & $-1,401$ & 1,476 & 1,175 & 0 \\
\hline & TOTAL HNL I & 731,399 & 124,407 & 275,176 & 326,891 & 4,925 \\
\hline & HNL II & & & & & \\
\hline 1 & Cibalia & 14,029 & 750 & 11,629 & 1,650 & 0 \\
\hline 2 & Zadar & 12,130 & 4,322 & 7,808 & 0 & 0 \\
\hline 3 & Dugopolje & 402 & -106 & 508 & 0 & 0 \\
\hline 4 & Gorica & 761 & 19 & 189 & 552 & 0 \\
\hline 5 & Hrvatski dragovoljac & 917 & -400 & 1,087 & 230 & 0 \\
\hline 6 & Imotski & 46 & -249 & 91 & 204 & 0 \\
\hline 7 & Lučko & 6,712 & 5,085 & 1,435 & 192 & 0 \\
\hline 8 & Rudeš & 550 & $-1,230$ & 292 & 1,488 & 0 \\
\hline 9 & Segesta & 298 & -726 & 1,017 & 0 & 6 \\
\hline 10 & Sesvete & 4,890 & 4,573 & 317 & 0 & 0 \\
\hline \multirow[t]{3}{*}{11} & Šibenik & 1,403 & $-5,550$ & 6,953 & 0 & 0 \\
\hline & TOTAL HNL II: & 42,137 & 6,489 & 31,326 & 4,315 & 6 \\
\hline & TOTAL HNL I \& II: & 773,536 & 130,896 & 306,502 & 331,206 & 4,931 \\
\hline
\end{tabular}

Note: npo - non-profit organization; plc - public limited company. $\quad$ Source: Football clubs' financial statements for 2014

Table 9 Selected ratios of liquidity and indebtedness of football clubs in 2014

\begin{tabular}{|c|c|c|c|c|c|}
\hline \multirow[b]{2}{*}{ No } & \multirow{2}{*}{ Football club } & \multicolumn{2}{|c|}{ Liquidity } & \multirow{2}{*}{ Debt ratio } & \multirow{2}{*}{$\begin{array}{c}\text { Capital } \\
\text { structure }\end{array}$} \\
\hline & & Current ratio & Cash ratio & & \\
\hline & HNL I & & & & \\
\hline 1 & Dinamo & 1.36 & 0.01 & 0.94 & 5.82 \\
\hline 2 & Zagreb & 0.54 & 0.00 & 5.52 & -1.22 \\
\hline 3 & Lokomotiva & 0.94 & 0.04 & 0.70 & 2.37 \\
\hline 4 & Slaven Belupo & 0.69 & 0.20 & 1.07 & 5.33 \\
\hline 5 & Hajduk & 0.50 & 0.02 & 0.37 & 0.60 \\
\hline 6 & Rijeka & 0.87 & 0.59 & 0.83 & 4.75 \\
\hline 7 & Split & 0.61 & 0.00 & 1.72 & -2.39 \\
\hline 8 & Osijek & 0.11 & 0.01 & 1.83 & -2.24 \\
\hline 9 & Istra 1961 & 0.14 & 0.02 & 0.81 & 4.16 \\
\hline \multirow[t]{3}{*}{10} & Inter Zaprešić & 0.83 & 0.00 & 2.12 & -1.89 \\
\hline & TOTAL HNL I: & 0.88 & 0.12 & 0.86 & 4.84 \\
\hline & HNL II & & & & \\
\hline 1 & Cibalia & 0.22 & 0.00 & 0.95 & 17.70 \\
\hline 2 & Zadar & 1.34 & 0.00 & 0.64 & 1.81 \\
\hline 3 & Dugopolje & 0.41 & 0.00 & 1.26 & -4.78 \\
\hline 4 & Gorica & 3.45 & 0.63 & 0.97 & 38.44 \\
\hline 5 & Hrvatski dragovoljac & 0.76 & 0.10 & 1.44 & -3.29 \\
\hline 6 & Imotski & 0.50 & 0.13 & 6.45 & -1.18 \\
\hline 7 & Lučko & 0.23 & 0.04 & 0.24 & 0.32 \\
\hline 8 & Rudeš & 1.30 & 1.03 & 3.24 & -1.45 \\
\hline 9 & Segesta & 0.13 & 0.01 & 5.32 & -1.40 \\
\hline 10 & Sesvete & 0.58 & 0.30 & 0.06 & 0.07 \\
\hline \multirow[t]{3}{*}{11} & Šibenik & 0.20 & 0.01 & 4.96 & -1.25 \\
\hline & TOTAL HNL II: & 0.55 & 0.03 & 0.85 & 5.49 \\
\hline & TOTAL HNL I \& II: & 0.85 & 0.11 & 0.86 & 4.87 \\
\hline
\end{tabular}


Quite unfavourable financial position of football clubs is confirmed also by indicators of liquidity and indebtedness. Liquidity is a characteristic of assets to convert into cash needed to meet liabilities. In other words, clubs' liquidity reveals the ability to timely meet liabilities.

Current ratio is calculated as the ratio of current assets to current liabilities putting in the relationship the coverage and the need for cash within one year. The value of the indicator greater than one means that the portion of current assets is financed from long-term sources, which is a characteristic of prudent financial management. Current liquidity of HNL I clubs is 0.88 and HNL II 0.55 (Table 9). Thus, HNL I clubs can cover with their current assets (on average) about $88 \%$ of current liabilities, and HNL II clubs only $55 \%$. While most football clubs have indicator values far lower than one, there are a few clubs (Dinamo, Zadar, Gorica and Rudeš) with the current ratio greater than one. This finding should be interpreted with caution because these clubs are mostly non-profit organizations with all financial assets characterized as short-term (for the purpose of comparative analysis), which made their value probably overrated. This doubt can best be checked by observing the cash ratio (ratio of cash and short-term liabilities) which reveals how much of the short-term liabilities can immediately be covered by the most liquid assets - cash. HNL I clubs can cover about $12 \%$, and HNL II clubs only $3 \%$ of current liabilities with cash (table 9).

The debt ratio is the ratio of total liabilities to total assets and shows what portion of total assets is purchased by borrowing. Preferably, the debt ratio should be 0.5 or less. However, HNL I clubs have the debt ratio of 0.86 , and HNL II clubs slightly less - 0.85. Only one HNL I club (Hajduk) and two HNL II clubs (Lučko and Sesvete) have a debt ratio of less than 0.5. Other clubs in general have several times higher values, additionally proving their poor financial position and the need for urgent interventions in their financial management in order to maintain the business continuity. The capital structure represents the ratio of debt (total liabilities) and equity. The high value of this indicator points to difficulties in meeting financial obligations - the problem of repaying the principal of the debt and interest payments. There is no consensus on what should be the value of this indicator, but the value of debt to equity ratio of $1: 1$ is commonly characterised as a conservative, a $2: 1$ as the debt ceiling. The debt to equity ratio for HNL I clubs in 2014 was $4.84: 1$, and for HNL II clubs 5.49:1. These values reveal that the borrowing limit has been broken even in the liberal financial framework.

\section{CONCLUSION}

Comparing the financial position of clubs from $\mathrm{HNL} I$ and II, it is clear that HNL I is a league of professional clubs with a total value of players of about HRK 1.3bn. Professional orientation of HNL I clubs is confirmed by the structure of players who are often purchased from abroad in order to achieve top sport results and generate operating revenues. Through such operations, clubs are to a lesser extent representing the public good. Therefore, it is reasonable to question their preferential treatment in terms of structure (organisation), preferential tax treatment and public subsidies.

In addition to the fact that non-profit organizations are generally not liable to income tax, the tax treatment of transfers of players is also questionable.

The financing structure of football clubs is dominated by liabilities. Especially worrying is the fact that of 21 clubs covered by the analysis, 10 clubs have a negative value of capital. Liabilities of Dinamo represent one half of long-term liabilities of all HNL I and HNL II clubs. A large part of these liabilities, which in 2014 increased almost seven times, refers to loans from banks and other creditors abroad.

Quite unfavourable financial position of football clubs in Croatia is confirmed by indicators of liquidity and indebtedness. According to all analysed parameters, clubs generally have a pretty bad financial position. This further indicates the need for urgent regulation of this sector and establishing a stable legal and institutional infrastructure for its long-term sustainability. It is vital to clearly profile the status of football clubs and their organizational structure. For publicly financed football clubs, concrete ways and amounts of funding, but also the purpose of funds collected in such a way should be prescribed. 
Financial results and created liabilities point to the fact that football has grown and transformed from financially less important social activity with obvious public benefits into a serious economic branch with increasingly represented private interests. Although only a small fraction of clubs in
Croatia (mostly those from HNL I) passed the transition to a professional sport, it is necessary to clearly delineate the operations of professional and amateur clubs. In line with their status, football clubs should be treated in the system of public financing.

\section{WORKS CITED}

Chadwick, S. \& Beech, J. (2004). The Business of Sport Management Essex: Prentice Hall.

Foster, G. \& Greyser, S. A. (2005). The business of Sport Management: Text and Cases on Strategy and Management. Mason: Thomson.

Gomez, S., Marti, C., \& Opazo, M. (2008). The Structural characteristics of Sport Organisation: Differentiations within Elite Spanish Professional Football Clubs. University Navara Wong Paper WB 751. doi: $10.2139 /$ ssrn.1269332

Kikulis, L. M., Slack, T., \& Hinings, B. (1995). Does decision-making make a difference? Patterns of change within Canadian national sporting organizations. Journal of Sport Management, 9(3), 135-153.

Morrow, S. (1997). Accounting for Football Players. Financial and Accounting Implications of 'Royal Club Liégois and Others $\mathrm{V}$ Bosman' for Football in the United Kingdom. Journal of Human Resource Costing and Accounting, 2(1), 55-71. doi: 10.1108/eb029035

Mourão, P. (2005). A importância do desenvolvimento regional na localização de equipas de futebol profissionais. O caso português 1970-1999. Revista Portuguesa de Estudos Regionais, (8), 31-45.

Mourão, P. (2010). Regional determinants of competitiveness: the case of European soccer teams. International Journal of Sport Finance, 5 (3), 222-234.

Mourao, P. R. \& Cima, C. C. (2011). What makes non-profit soccer teams run? A panel data approach using a sample of Braga teams. Financial Theory and Practice, 36(2), 199-220. doi: 10.3326/fintp.36.2.4

Nagy, Z., I. (2012). Financing Methods in Professional Football. Working paper 1201.

Sloan, P. (1971). The Economics of Professional Football: The Football Club as a Utility Maximiser. Scottish Journal of Political Economy, 18(2), 121-146. doi: 10.1111/j.1467-9485.1971.tb00979.x

Szymanski, S. \& Hall, S. (2003). Making money out of football. London: The Business School, Imperial College.

UEFA (2012). Club licensing and Financial Fair Play regulations 2012. Geneva: UEFA.

Van Uden, J. (2005). Transforming a football club into a total experience entertainment company: implication for management. Managing Leisure, 10(3), 184. doi: 10.1080/13606710500239087

Received for publication: 11.03 .2016

Revision received: $\quad 28.05 .2016$

Accepted for publication: 10.06 .2016

\section{How to cite this article?}

Style - APA Sixth Edition:

Bajo, A., Primorac, M., \& Grubisic, L. (2016, July 15). Organisation and financing of football clubs in Croatia. (Z. Čekerevac, Ed.) MEST Journal, 4(2), 11-22. doi:10.12709/mest.04.04.02.02

Style - Chicago Sixteenth Edition:

Bajo, Anto, Marko Primorac, and Lucija Grubisic. 2016. "Organisation and financing of football clubs in Croatia." Edited by Zoran Čekerevac. MEST Journal (MESTE) 4 (2): 11-22. doi:10.12709/mest.04.04.02.02. 
Style - GOST Name Sort:

Bajo Anto, Primorac Marko and Grubisic Lucija Organisation and financing of football clubs in Croatia [Journal] // MEST Journal / ed. Čekerevac Zoran. - Belgrade : MESTE, July 15, 2016. 2 : Vol. 4. - pp. 11-22.

Style - Harvard Anglia:

Bajo, A., Primorac, M. \& Grubisic, L., 2016. Organisation and financing of football clubs in Croatia. MEST Journal, 15 July, 4(2), pp. 11-22.

Style - ISO 690 Numerical Reference:

Organisation and financing of football clubs in Croatia. Bajo, Anto, Primorac, Marko and Grubisic, Lucija. [ed.] Zoran Čekerevac. 2, Belgrade : MESTE, July 15, 2016, MEST Journal, Vol. 4, pp. 11-22. 